\title{
Effect of grass-silage vs. hay diet on the characteristics of cheese: interactions with the cheese model
}

\author{
Isabelle VERDIER-METZa*, Bruno MARTIN ${ }^{\mathrm{b}}$, Philippe PRADEL $^{\mathrm{c}}$, \\ Hélène ALBOUY ${ }^{d}$, Sophie HULINe ${ }^{e}$, Marie-Christine MONTEL ${ }^{\mathrm{a}}$, \\ Jean-Baptiste COULON ${ }^{b}$ \\ a Unité de Recherches Fromagères, Inra, 36 rue de Salers, 15000 Aurillac, France \\ b Unité de Recherche sur les Herbivores, Inra, 63122 Saint-Genès Champanelle, France \\ c Domaine de la Borie, Inra, 15190 Marcenat, France \\ d École Nationale de l'Industrie Laitière et de la Viande, 15000 Aurillac, France \\ e Comité Interprofessionnel des Fromages, 15000 Aurillac, France
}

Received 7 January 2005 - Accepted 21 April 2005

Published online 1 October 2005

\begin{abstract}
Twenty-eight multiparous dairy cows were divided into 2 groups: one group (S) was fed a ray-grass silage diet and the other one $(\mathrm{H})$ a hay-based diet. The milk produced by these cows was used to make Saint-Nectaire-type cheese on one day and Cantal cheese on the following day, using identical, controlled cheesemaking techniques for each model. The $\mathrm{S}$ cheeses, regardless of the model, had higher fat $(P<0.01)$ and fat in dry matter $(P<0.05)$ contents but lower total nitrogen content $(P<0.001)$ and exhibited a more yellow tone. The differences in sensory characteristics were more pronounced in Cantal cheeses: H cheeses had more "butter" and "grass" odours, "citrus fruits" - "hay" -"hazelnut" aromas and more persistent flavour than S cheeses, which showed more "alcohol" odour, "chemical" aroma and had a less "melting", "mellow" texture. The dietary effect was greater with Cantal cheese because of a diet / cheese model interaction.
\end{abstract}

grass silage / hay / milk / cheese / sensory characteristic

摘要 - 青贮牧草和干草饲料对干酪特性的影响: 对不同类型干酪之间的相互作用。将 28 头 经产奶牛分成 $\mathrm{S}$ 组和 $\mathrm{H}$ 组, $\mathrm{S}$ 组只喂饲青败黑麦草, $\mathrm{H}$ 组喂饲干草基饲料。这些乳牛达到 产奶期时, 2 组奶牛产的牛奶交替地加工 Saint-Nectaire 干酪 (圣耐克泰里干酪, 产于法国 中部）和 Cantal 干酪 (法国硬干酪), 即取一天的牛奶用来加工 Saint-Nectaire 干酪, 隔一天 的牛奶用来加工 Cantal 干酪, 每种干酪都严格控制加工条件使其保持一致。 $\mathrm{S}$ 组牛奶加工 的两种干酪其脂肪含量都较高 $(P<0.01)$, 脂肪占干物质的含量也较高 $(P<0.05)$, 但是总氮 含量较低 $(P<0.001)$, 干酪呈现较黄的颜色。Cantal 干酪在感官性质上则表现出非常明显的 差异, $\mathrm{H}$ 组牛奶加工成的干酪比 $\mathrm{S}$ 组干酪有明显的奶油味、草香味和柑橘味, 并具有轻微 的干草味和榛子味, 而且 $\mathrm{H}$ 组干酪的风味比 $\mathrm{S}$ 组稳定; $\mathrm{S}$ 组干酪表现出较强的乙醇味和化 学香料味, 熔融性较差并缺少细淢柔和的质构。由于不同类型饲料与不同类型干酪之间存 在着相互作用, 饲料对 Cantal 干酪特性影响较大。

牧草青咜 / 干草 / 牛乳 / 干酪 / 感官特性

* Corresponding author ( 通讯作者): iverdier@clermont.inra.fr 
Résumé - Effet d'une alimentation à base d'herbe ou de foin sur les caractéristiques du fromage : interactions avec le modèle technologique. Vingt-huit vaches laitières ont été divisées en deux groupes : l'un $(\mathrm{S})$ a reçu un régime à base d'ensilage de ray-grass et l'autre $(\mathrm{H})$ à base de foin. Le lait de ces animaux a été transformé un jour en fromage de type Saint-Nectaire et un autre jour en fromage de Cantal, dans des conditions technologiques contrôlées et identiques d'une fabrication à l'autre pour chaque type de fromage. Quelque soit le modèle fromager, les fromages $\mathrm{S}$ ont eu des taux plus élevés de matière grasse $(P<0,01)$ et d'extrait sec $(P<0,05)$ mais une plus faible teneur en azote total $(P<0,001)$ et ils ont été plus jaunes. Les différences de caractéristiques sensorielles ont été plus marquées dans le cas du Cantal : les fromages $\mathrm{H}$ ont été caractérisés par des odeurs « beurre » et « herbe », des arômes « agrumes », « foin », « noisette », et une flaveur plus persistante que les fromages $S$, qui ont révélé une odeur d' «alcool », un arôme " chimique » et une texture moins « fondante » et «moelleuse ». L'effet régime alimentaire a été plus marqué dans le cas du fromage de Cantal révélant une interaction entre l'alimentation des animaux et le modèle fromager.

ensilage d'herbe / foin / lait / fromage / caractérisation sensorielle

\section{INTRODUCTION}

Over the last decade, some scientists have explored the relationships that exist between the conditions under which milk is produced and the sensory properties of cheese, as these upstream factors, those related to animal feeding in particular, have increasingly been the focus of consumers' concern. These factors are particularly important in the case of labelled products (Protected Designation of Origin [PDO], Protected Geographical Indication [PGI], etc.), where any raw material modification during processing is restricted or prohibited and close links with milk production conditions are claimed to be the basis for the "terroir" notion [12]. Studies on the effects of animals' characteristics or feeding provide a large number of original data, recently reviewed by Coulon et al. [9]. Nevertheless, the effect of upstream factors on cheese sensory properties may vary for a given cheese variety according to cheesemaking parameters such as partial skimming [31], pasteurisation [11], acidification kinetics [19] or ripening time [3]. The effects of upstream factors may also vary according to the cheese varieties. Indeed, the mechanisms involved in the effectiveness of upstream factors are linked to variations in milk chemical or microbial characteristics according to dairy cows' feeding characteristics. The influence of change in milk characteristics on cheese properties may vary according to the cheese variety. For instance, the weight of feeding factor effects on milk fat properties is likely to be all the more important as the cheese fat content is high. So, we hypothesised that the effect of upstream factors observed in one cheese model cannot necessarily be extrapolated to other cheese models. In this study we were interested in the differences in upstream factors' expression according to the cheese model.

The aim of this study was to describe the chemical composition and the sensory characteristics of two cheese models (SaintNectaire and Cantal) made with the milk produced by cows fed a diet based either on hay or on grass silage. We chose these two diets because the issue of grass preservation in the form of silage has long been a matter of debate within the PDO cheese channels.

\section{MATERIALS AND METHODS}

\subsection{Experimental design}

Twenty-eight Holstein ( $\mathrm{HO}, n=12)$, Montbéliarde (MO, $n=8$ ) and Tarentaise (TA, $n=8)$ cows were divided into two equal groups of 14 cows (4 MO, 4 TA and $6 \mathrm{HO})$. These animals had calved between 15 November and 10 January. The allelic frequency of the $\kappa$-casein $\mathrm{B}$ variant was equivalent in both groups (39\% and $42 \%$ ). The trial began on 7 February. During a first 3 -week period (P1), both groups were fed the same diet based on maize silage $(90 \%$ dry matter (DM) of the diet) with a concentrate mixture (61\% barley, $22 \%$ soybean 
meal and $17 \%$ urea). Then, group S was fed a ray-grass silage diet $(90 \% \mathrm{DMI})$ for 7 weeks (P2), and group $\mathrm{H}$ was fed a haybased diet (90\% DMI). Ryegrass silage was prepared on 8 June from a first-cut of temporary grassland (sowed 3 years ago and in the majority composed of raygrass) with some formic acid $\left(3 \mathrm{~L} \cdot \mathrm{t}^{-1}\right)$. The hay came from mountain natural grassland harvested on 26 May and barn-dried: it was composed principally of $34 \%$ Lolium perenne, $18 \%$ Dactylis glomerata, $13 \%$ Poa trivialis, $7 \%$ Agrostis tenuis and 6\% Trifolium repens. Each cow received restricted amounts of forage and concentrate according to their bodyweight and milk yield recorded in weeks 2 and 3 of P1, so as to be isoenergetic and to cover the cows' nitrogen requirements. The concentrate used was a mixture of soybean meal and barley. Throughout the entire experiment, the cows were given a mineral and vitamin additive at a rate of $200 \mathrm{~g} \cdot \mathrm{d}^{-1}$.

\subsection{Cheesemaking}

During the last 5 weeks of P2, the raw milk obtained from $\mathrm{S}$ and $\mathrm{H}$ cows at the morning milking was alternately processed every other day into Saint-Nectaire-type cheese and into Cantal cheese. These two French cheeses are PDO-labelled.

The milks were processed without any standardisation. The Saint-Nectaire-type cheeses $(\mathrm{Sn})$ were manufactured in an experimental dairy plant equipped with two 40 -L vats. Overall, 10 vats were processed and 20 cheeses manufactured. In each vat, $32 \mathrm{~kg}$ of milk were heated to $33{ }^{\circ} \mathrm{C}$ and inoculated with a lyophilised, mesophilic and thermophilic starter culture $\left(0.1 \mathrm{~g} \cdot \mathrm{kg}^{-1}\right.$ MA400 and $2.35 \mathrm{~g} \cdot \mathrm{kg}^{-1}$ MY800, respectively; Texel, Dangé-Saint-Romain, France) reconstituted in sterile skimmed milk $\left(100 \mathrm{~g} \cdot \mathrm{L}^{-1}\right)$, with a ripening starter (7.10 ${ }^{6}$ germs $\cdot L^{-1}$, Groupement d'Intérêt Economique, Laboratoire Interprofessionnel de Production, Aurillac, France) and with $33 \mathrm{~g} \cdot \mathrm{kg}^{-1}$ of a $520 \mathrm{mg}$ active chy$\operatorname{mosin} \cdot \mathrm{L}^{-1}$ rennet (SBI, Gand-Gassiot, Beaune, France). Clotting time was visually assessed. One hour later, the curd was cut for $3 \mathrm{~min}$, stirred for $6 \mathrm{~min}$ and left to rest for $4 \mathrm{~min}$. While the curd was kept on the vat bottom with a grille, the whey was drained. The curd was cut into 24 cubes to extract the whey. These cubes were then placed into two moulds and shaped with a moulding machine (Duprat, Murat, France). Each cheese was rolled up in a cheese cloth and a hoop, salted on the surface $(40 \mathrm{~g} \mathrm{NaCl}$ per side) and placed in polypropylene moulds. These cheeses were pressed for $24 \mathrm{~h}$ under 3 bar, then ripened for 7 weeks in a cellar at $10{ }^{\circ} \mathrm{C}$ and $95 \%$ minimum relative humidity.

Small-size Cantal cheeses $(10 \mathrm{~kg}$ instead of 40) called "Cantalets" (also PDOlabelled), were manufactured from $110 \mathrm{~L}$ of $\mathrm{S}$ or $\mathrm{H}$ milk. Overall, 10 vats were processed and produced 10 Cantalet (Ca) cheeses. Once heated to $33{ }^{\circ} \mathrm{C}$, raw milks were inoculated with $0.2 \mathrm{~g}$ of a lyophilised, mesophilic starter culture (Flora Danica Direct, Sochal, Saint-Etienne-de-Chomeil, France) reconstituted in sterile skimmed milk $\left(100 \mathrm{~g} \cdot \mathrm{L}^{-1}\right)$, with a ripening starter ( $2 \mathrm{~mL}$ of Monilev and $1.5 \mathrm{~mL}$ of Penbac, Laboratoire Interprofessionnel de Production, Aurillac, France) and with $0.33 \mathrm{~g} \cdot \mathrm{kg}^{-1}$ of a rennet containing $520 \mathrm{mg}$ active chy$\operatorname{mosin} \cdot \mathrm{L}^{-1}$. Forty-five minutes later, the curd was cut for $5 \mathrm{~min}$ to produce pellets 5$6 \mathrm{~mm}$ in diameter. The curd-whey mixture was then blended for $12 \mathrm{~min}$ and left to stand for $7 \mathrm{~min}$. After extraction of the whey, the curd was placed in a pressing tray where it was pressed, cut into $15-\mathrm{cm}$-sided cubes and turned 12 times in about $3 \mathrm{~h}$ in order to reach $50 \%$ dry matter. After pressing, the curd cubes were left to drain for $24 \mathrm{~h}$ at $20^{\circ} \mathrm{C}$ and were pounded into grains $20 \mathrm{~mm}$ in diameter. The mixture was salted with $20 \mathrm{~g} \cdot \mathrm{kg}^{-1}$ dry salt and left to stand for $6 \mathrm{~h}$ at $20^{\circ} \mathrm{C}$ before one cheese per vat was formed in a cloth mould and pressed for $24 \mathrm{~h}$ at $13{ }^{\circ} \mathrm{C}$. Cheeses were placed in a ripening cellar for 3 months at $10{ }^{\circ} \mathrm{C}$ and $95 \%$ minimum relative humidity.

\subsection{Analyses}

\subsubsection{Milks}

$\mathrm{pH}$ (at $20^{\circ} \mathrm{C}$ ), protein, fat and lactose contents (infrared method, Milkoscan 4000, 
Foss System, Hillerod, Denmark), urea content (dimethyl amino benzaldehyde (DMAB) method), calcium (flame atomic absorption spectrometric method [15]) and phosphorus contents (spectrometric method [14]), somatic cell count (Fossomatic 5000, Foss System, Hillerod, Denmark [16]), milk total bacterial count [2] and butyric spore count [6] were assessed on a representative sample of each vat. Coagulation properties (rennet clotting time, curd firming time required to achieve $20 \mathrm{~mm}$ firmness and curd firmness after $30 \mathrm{~min}$ ) were also evaluated, using a Formagraph apparatus according to the method proposed by McMahon and Brown [21] as described in Verdier-Metz et al. [29].

The Cinac system (Ysebaert Dairy Division, Frepillon, France, [7]) was used to measure the acidification properties of the milk. pH measurements were made every $10 \mathrm{~min}$ for $24 \mathrm{~h}$ according to temperature variation: $4 \mathrm{~h}$ at $33{ }^{\circ} \mathrm{C}$ then $2.5 \mathrm{~h}$ at $26^{\circ} \mathrm{C}$ then a progressive decrease to $20^{\circ} \mathrm{C}$ in order to reproduce the thermal cycle of a pressed cheese. Three conditions were studied for each milk: raw milk alone, and the same raw milk inoculated with the two starters used for cheesemaking (see Sect. 2.2).

During the last week of each period (P1 and P2), 2- and 9-triangle sensory analyses [1] were, respectively performed by a panel of 10 or 11 assessors to compare the two milks, under a red light and on milk heated to $45^{\circ} \mathrm{C}$. The assessors were free to specify which criteria allowed them to identify the unseeded raw milk sample.

\subsubsection{Cheeses}

The $\mathrm{pH}$ was measured at $20^{\circ} \mathrm{C}$ by introducing an Ingold electrode (Ingold France, Paris, France) into some ground cheese. Dry matter content was determined by desiccation at $103^{\circ} \mathrm{C}$ for $24 \mathrm{~h}$ [13]. The fat content of the cheeses was measured by butyrometric method [17]. Total nitrogen (TN), water-soluble nitrogen (WSN) and phosphotungstic acid soluble nitrogen (PTSN) were measured using the methods described by Ardö [4].The measurements of the curd colour of cheeses were detailed in Verdier-Metz et al. [29].
The rheological method used for the $\mathrm{Ca}$ cheeses was uniaxial compression at constant displacement rate. A Lloyd testing machine equipped with parallel plates and a 500-N load cell was used. The displacement rate was $50 \mathrm{~mm} \cdot \mathrm{min}^{-1}$. Ten cylindrical specimens were tested for each cheese sample. The cylinders ( $20 \mathrm{~mm}$ diameter) were cut with a cutting device to a 20 -mm height. Test pieces were stored in a small airtight box (to avoid desiccation) for $1 \mathrm{~h}$ to permit relaxation before testing at $20^{\circ} \mathrm{C}$. Force and displacement data were recorded. The force and height variation data were computed as stress/strain curves.

In the Sn cheeses, we measured the resistance to the penetration of a $2-\mathrm{mm}$ diameter needle opposed from the curd cheese. The needle was fixed on a 20-N load cell from the Lloyd testing machine.

All ripened cheeses were submitted to 8 assessors from INRA's Aurillac laboratory, who rated each cheese for body and texture (0-5 score) and taste (0-10 score) according to the criteria described by the Interprofession.

The cheeses were assessed by two panels of 10 trained assessors: a "Saint-Nectaire" panel scored the intensity of 33 attributes (3 for texture, 13 for odour, 17 for aroma and flavour) on a structured scale from 0 to 10 , and another "Cantal" panel scored the intensity of 43 attributes ( 5 for texture, 15 for odour, 23 for aroma and flavour) on a structured scale from 0 to 7 .

\subsubsection{Statistical analyses}

The data were processed by analysis of variance [25]. The statistical model included the effect of the diet for data related to milk. By including in the statistical model the effect of the milk's further use (for $\mathrm{Ca}$ or $\mathrm{Sn}$ cheesemaking) we were able to verify that the milks used in the two cheesemaking processes were equivalent (not shown). For milk clotting and acidification ability we pooled the data obtained for milk further used for Sn and Ca production and we included the dietary effect in the model. For the cheese chemical, rheological and sensory data, analyses of variance were performed separately for $\mathrm{Ca}$ and $\mathrm{Sn}$, 
Table I. Composition and characteristics of the milks.

\begin{tabular}{|c|c|c|c|c|}
\hline Diet & $\mathrm{S}$ & $\mathrm{H}$ & $\mathrm{RSD}^{1}$ & Significance $^{2}$ \\
\hline \multicolumn{5}{|l|}{ Composition } \\
\hline Fat $\left(g \cdot \mathrm{kg}^{-1}\right)$ & 37.8 & 37.3 & 6.20 & ns \\
\hline Protein $\left(\mathrm{g} \cdot \mathrm{kg}^{-1}\right)$ & 29.6 & 30.9 & 0.80 & $* *$ \\
\hline Lactose $\left(\mathrm{g} \cdot \mathrm{kg}^{-1}\right)$ & 47.4 & 47.8 & 0.42 & ns \\
\hline Urea $\left(g \cdot \mathrm{kg}^{-1}\right)$ & 0.25 & 0.38 & 0.06 & $* * *$ \\
\hline Phosphorus $\left(\mathrm{g} \cdot \mathrm{kg}^{-1}\right)$ & 0.85 & 0.87 & 0.02 & $*$ \\
\hline Calcium $\left(\mathrm{g} \cdot \mathrm{kg}^{-1}\right)$ & 1.19 & 1.20 & 0.04 & ns \\
\hline Somatic cell count $\left(10^{3} \cdot \mathrm{mL}^{-1}\right)$ & 66.9 & 59.7 & 35.5 & $\mathrm{~ns}$ \\
\hline \multicolumn{5}{|c|}{ Acidification properties without starter } \\
\hline $\mathrm{pH}$ at $\mathrm{t}=0$ & 6.60 & 6.59 & 0.05 & $\mathrm{~ns}$ \\
\hline $\mathrm{pH}$ at $\mathrm{t}=24 \mathrm{~h}$ & 6.20 & 6.23 & 0.54 & $\mathrm{~ns}$ \\
\hline $\operatorname{Vmax}(\mathrm{dpH} / \mathrm{dt})$ & -0.001 & -0.002 & 0.001 & ns \\
\hline $\operatorname{Tmax}(\min )$ & 1366 & 1410 & 60 & ns \\
\hline pHmax & 6.26 & 6.25 & 0.50 & ns \\
\hline \multicolumn{5}{|l|}{ Acidification properties with MY800 } \\
\hline $\mathrm{pH}$ at $\mathrm{t}=24 \mathrm{~h}$ & 4.73 & 4.74 & 0.14 & $\mathrm{~ns}$ \\
\hline $\operatorname{Vmax}(\mathrm{dpH} / \mathrm{dt})$ & -0.004 & -0.006 & 0.001 & $\mathrm{~ns}$ \\
\hline $\operatorname{Tmax}(\min )$ & 272 & 254 & 32 & $\mathrm{~ns}$ \\
\hline pHmax & 6.18 & 6.13 & 0.15 & $\mathrm{~ns}$ \\
\hline \multicolumn{5}{|l|}{ Processing properties } \\
\hline Renneting clotting time (min) & 23.4 & 22.8 & 2.8 & $\mathrm{~ns}$ \\
\hline Curd firming time (min) & 10.6 & 10.6 & 1.36 & $\mathrm{~ns}$ \\
\hline Curd firmness (mm) & 33.8 & 35.7 & 2.47 & $\mathrm{~ns}$ \\
\hline
\end{tabular}

${ }^{1}$ Residual standard deviation.

2 Significance of difference: $* P<0.05$; $* * P<0.01$; *** $P<0.001$; ns: not significant.

by including the dietary effect in the model, and in addition the assessor effect for sensory data only. For the cheese chemical data only, we also performed a single analysis of variance for both $\mathrm{Ca}$ and $\mathrm{Sn}$, including in the model the effects of diet, cheese variety and the interaction.

\section{RESULTS}

\subsection{Milk characteristics}

The milks used for cheesemaking had similar, very low total bacterial counts: 2600 and $1800 \mathrm{cfu} \cdot \mathrm{mL}^{-1}$ for $\mathrm{S}$ and $\mathrm{H}$ milks, respectively. Their coliform and butyric spore counts never exceeded $500 \mathrm{cfu} \cdot \mathrm{mL}^{-1}$ and 200 spores. $\mathrm{L}^{-1}$, respectively. The $\mathrm{H}$ milks had higher protein, urea $(P<0.001)$ and phosphorus $(P<0.05)$ contents than the $\mathrm{S}$ milks (Tab. I). In contrast, fat, lactose and calcium contents and somatic cell counts were similar in both diets. The milk $\mathrm{pH}$ and clotting properties at native or standardised $\mathrm{pH}$ were similar in $\mathrm{H}$ and $\mathrm{S}$ milks and curd firmness was slightly higher on average (not significant) in $\mathrm{H}$ milks. Both milks also had a similar behaviour during spontaneous acidification (Tab. I) and acidification with the two experimental starters (MY800: Tab. I and Flora Danica: results not shown).

From the sensory viewpoint (Tab. II), $45 \%$ of the assessors were able to identify 
Table II. Milk sensory comparison tests (triangle test).

\begin{tabular}{lcc}
\hline & P1 & P2 \\
\hline $\begin{array}{l}\text { Overall number of } \\
\text { tests }\end{array}$ & 21 & 95 \\
$\begin{array}{l}\text { Number of right } \\
\text { answers }\end{array}$ & 4 & 43 \\
Significance $^{1}$ & ns & $* *$ \\
\hline
\end{tabular}

${ }^{1}$ Significance of difference: $* * P<0.05$; ns: not significant.

the cow groups the milks came from $(P<0.05)$, although they did not find any differences during the pre-experimental period (P1). Among the right answers, $23 \%$ of the assessors claimed to have identified milks from their texture and $51 \%$ from their taste, which was globally qualified as "stronger" for the S milk. The other assessors did not explain how they differentiated the samples.

\subsection{Cheese characteristics}

Both $\mathrm{Ca}$ and $\mathrm{Sn}$ cheeses made from $\mathrm{S}$ milk (Tab. III) had a higher fat content and fat in dry matter and a lower total nitrogen content $(P<0.01)$. They were also yellower $(P<0.001)$ than $\mathrm{H}$ cheeses. Neither the soluble nitrogen fractions nor the instrumental rheological measurements revealed any significant differences between diets. The dietary effect was the same in the two cheese varieties: there was no significant interaction (results not shown) except for the curd colour where the effect of diet on the red-green index was low but opposite on average in the two cheese varieties.

Table III. Effect of diet on the cheeses' characteristics.

\begin{tabular}{|c|c|c|c|c|c|c|c|c|}
\hline \multirow{2}{*}{$\begin{array}{l}\text { Cheese } \\
\text { Diet }\end{array}$} & \multicolumn{4}{|c|}{ Cantalet } & \multicolumn{4}{|c|}{ Saint-Nectaire } \\
\hline & $\mathrm{S}$ & $\mathrm{H}$ & $\mathrm{RSD}^{1}$ & Sig. $^{2}$ & $\mathrm{~S}$ & $\mathrm{H}$ & $\mathrm{RSD}^{1}$ & Sig. ${ }^{2}$ \\
\hline \multicolumn{9}{|l|}{ Composition } \\
\hline $\mathrm{pH}$ & 5.40 & 5.38 & 0.07 & $\mathrm{~ns}$ & 5.17 & 5.19 & 0.04 & ns \\
\hline Dry matter $(\%)$ & 62.3 & 62.0 & 0.86 & ns & 55.7 & 54.4 & 0.85 & $*$ \\
\hline Fat $\left(\mathrm{g} \cdot \mathrm{kg}^{-1}\right)$ & 32.5 & 31.3 & 1.02 & ns & 29.7 & 27.9 & 0.60 & $* *$ \\
\hline Fat in dry matter (\%) & 52.1 & 50.5 & 1.67 & ns & 53.3 & 51.4 & 0.99 & $*$ \\
\hline Total Nitrogen (TN) & 6.55 & 6.73 & 0.08 & $* *$ & 6.19 & 6.49 & 0.06 & $* * *$ \\
\hline Water-soluble Nitrogen / TN (\%) & 14.1 & 14.2 & 1.97 & ns & 14.2 & 13.5 & 0.76 & ns \\
\hline PTSN / TN (\%) & 4.9 & 4.6 & 1.02 & ns & 3.7 & 3.6 & 0.49 & ns \\
\hline PTSN / WSN (\%) & 34.2 & 32.3 & 3.52 & ns & 26.2 & 26.4 & 3.52 & ns \\
\hline \multicolumn{9}{|l|}{ Colour measurements } \\
\hline $\mathrm{L}$ & 80.7 & 81.3 & 0.45 & ns & 83.0 & 83.7 & 0.78 & ns \\
\hline Red-green index & -0.9 & -1.1 & 0.05 & $* * *$ & -0.3 & -0.1 & 0.19 & ns \\
\hline Blue-yellow index & 33.4 & 29.5 & 0.65 & $* * *$ & 28.4 & 23.5 & 0.76 & $* * *$ \\
\hline \multicolumn{9}{|l|}{ Instrumental rheological measurements } \\
\hline Fracture strength $(\mathrm{N})$ & & & & & 2.68 & 2.55 & 0.41 & $\mathrm{~ns}$ \\
\hline $\begin{array}{l}\text { Strength }\left(\mathrm{N} \cdot \mathrm{cm}^{-2}\right) \text { for } 60 \% \\
\text { deformation }\end{array}$ & 81.1 & 79.4 & 3.85 & $\mathrm{~ns}$ & & & & \\
\hline
\end{tabular}

\footnotetext{
${ }^{1}$ Residual standard deviation.
}

${ }^{2}$ Significance of difference: $* P<0.05$; $* * P<0.01$; $* * * P<0.001$; ns: not significant. 
The cheese sensory characteristics (Tab. IV) were analysed by two different panels. For Sn cheeses, only 2 of the 33 attributes significantly differed between the diets; $\mathrm{S}$ cheeses had a more gritty texture and a less rancid aroma. In addition, no differences were observed in the global acceptance of curd and flavour. Conversely, more significant differences between diets were observed for $\mathrm{Ca}$ cheeses. First, H cheeses had higher scores for curd and flavour acceptance. Eight of the 43 attributes significantly differed between the diets $(P<0.05)$. H cheeses were characterised by their more pronounced "butter" and "grass" odours and "citrus fruits" aroma and a more persistent flavour than $\mathrm{S}$ cheeses. The aroma of $\mathrm{H}$ cheeses was also slightly $(P<0.1)$ more "hay" and "hazelnut". The S cheeses were characterised by a pronounced "alcohol" odour and a more chemical aroma, attributes generally carrying a negative connotation. They also had a less "melting" and "mellow" texture than the $\mathrm{H}$ cheeses.

\section{DISCUSSION}

In our study, the higher protein and urea contents in milk from cows fed hay probably resulted from higher energetic and nitrogen inputs rather than from the forage preservation method, as observed in other studies [8]. Indeed, silage intake was lower than estimated in the experimental design. This resulted in higher energy and nitrogen supplies for $\mathrm{H}$ than $\mathrm{S}$ cows (14.4 vs. 13.0 UF. $\mathrm{cow}^{-1} \cdot \mathrm{d}^{-1}$ and 1690 vs. $1140 \mathrm{~g}$ PDI $\cdot \operatorname{cow}^{-1} \cdot \mathrm{d}^{-1}$, respectively) and also in higher milk yield (18.0 vs. $\left.17.0 \mathrm{~kg} \cdot \operatorname{cow}^{-1} \cdot \mathrm{d}^{-1}\right)$. It was surprising that differences in milk protein contents did not induce any significant modification of the renneting suitability, insofar as the allelic frequency of $\kappa$-casein $B$ variant was similar in both batches [24]. Nevertheless, the H milk produced firmer gel on average and the differences in protein contents remained limited and were not sufficient to have a significant effect on the milk renneting capacity. The low spontaneous acidification rate of the milks was due to their low microbial counts, as already observed [22]. This study showed that the diets tested did not alter milk suitability for acidification, either spontaneous or with starters. This original result complements scattered data on the effect of cows' diet on milk acidification capacity [5]: in particular, it was demonstrated that milk from maize-silage-fed cows was slowly fermentable and the milks of herds fed with concentrates and silage were characterised by slower acidification. However, in our case, this absence of effect is not surprising insofar as, on the one hand, the quantitative characteristics of the milk flora in both diets were bordering on each other and, on the other hand, an investigation on anti-microbial molecules such as lactoperoxidase and thiocyanate showed similar levels in the milks from silage and hay diets [20]. Also, we demonstrated the existence of a dietary effect on milk sensory characteristics. The differences observed by the assessors were not linked to the yellower colour of the $\mathrm{S}$ milk because tasting was performed in a red light environment. The differences noted were ascribed, on the one hand, to texture, although both batches of milk had similar protein and fat contents, and on the other hand, to flavour, qualified with some difficulty by the majority of assessors as slightly stronger in "silage" milk. This last result is in concordance with earlier studies where undesirable flavours were ascribed to the presence of grass silage in the diet $[26,27]$ and where the volatile compounds responsible for these differences could be identified [23]. The differences noted in our study appeared to be weaker than those previously described. Indeed, even if differences were significant, barely half of the assessors were able to distinguish the milks. The good quality of our grass silage processing and preservation could explain its low impact on milk sensory characteristics. Regarding the cheeses, grass silage led to yellower $\mathrm{Ca}$ and $\mathrm{Sn}$ cheeses because of a better preservation of carotenoids when grass is preserved as silage [18, 30]. In Sn cheeses, the low effect of the forage under test conditions on cheese sensory characteristics, except curd colour, was in accordance with our earlier results where we observed a very low effect of grass silage preservation on sensory 
Table IV. Effect of diet on cheese sensory characteristics.

\begin{tabular}{|c|c|c|c|c|c|c|c|c|}
\hline \multirow{2}{*}{$\begin{array}{l}\text { Cheese } \\
\text { Diet }\end{array}$} & \multicolumn{4}{|c|}{ Cantalet } & \multicolumn{4}{|c|}{ Saint-Nectaire } \\
\hline & $S$ & $\mathrm{H}$ & $\mathrm{RSD}^{1}$ & $\mathrm{Sig}^{2}$ & $S$ & $\mathrm{H}$ & $\mathrm{RSD}^{1}$ & Sig. $^{2}$ \\
\hline \multicolumn{9}{|l|}{ Appreciation } \\
\hline Curd (/5) & 3.41 & 3.67 & 0.35 & $* *$ & 3.66 & 3.74 & 0.31 & ns \\
\hline Flavour (/10) & 6.44 & 6.95 & 0.69 & $* *$ & 6.69 & 6.95 & 0.67 & ns \\
\hline \multicolumn{9}{|l|}{ Sensory profile } \\
\hline Elastic texture & 5.1 & 5.5 & 1.06 & ns & & & & \\
\hline Firm texture & 4.6 & 4.7 & 1.11 & ns & 4.5 & 4.3 & 1.35 & ns \\
\hline Melting texture & 3.2 & 3.9 & 0.89 & $* * *$ & 4.3 & 4.4 & 1.28 & ns \\
\hline Mellow texture & 2.7 & 3.3 & 0.95 & $* *$ & & & & \\
\hline Gritty texture & & & & & 0.9 & 0.6 & 0.74 & $*$ \\
\hline Crumbly texture & 3.4 & 3.6 & 1.26 & $\mathrm{~ns}$ & & & & \\
\hline Odour intensity & 3.7 & 3.7 & 0.83 & ns & 5.0 & 4.9 & 1.13 & $\mathrm{~ns}$ \\
\hline Citrus fruits odour & 1.0 & 1.1 & 0.99 & ns & & & & \\
\hline Sour odour & & & & & 0.4 & 0.5 & 0.59 & ns \\
\hline Alcohol odour & 0.3 & 0.02 & 0.36 & $* * *$ & & & & \\
\hline Garlic odour & 0.8 & 0.6 & 0.74 & ns & & & & \\
\hline Butter odour & 2.3 & 3.0 & 1.36 & * & 1.4 & 1.0 & 0.99 & $\mathrm{~ns}$ \\
\hline Caramel odour & 0.6 & 0.5 & 0.99 & ns & & & & \\
\hline Chemical odour & 0.2 & 0.4 & 1.1 & ns & & & & \\
\hline $\begin{array}{l}\text { Acidified cream } \\
\text { odour }\end{array}$ & 0.8 & 0.5 & 0.95 & ns & & & & \\
\hline Fresh cream odour & 1.8 & 2.3 & 1.56 & ns & 1.3 & 1.6 & 0.99 & ns \\
\hline Silage odour & & & & & 0.03 & 0.08 & 0.23 & ns \\
\hline Spicy odour & 0.3 & 0.4 & 0.72 & ns & & & & \\
\hline $\begin{array}{l}\text { Lactic acid } \\
\text { fermentation odour }\end{array}$ & & & & & 0.7 & 1.0 & 0.87 & ns \\
\hline Hay odour & 0.8 & 0.7 & 0.92 & ns & 0.2 & 0.2 & 0.51 & ns \\
\hline Fruity odour & & & & & 0.8 & 0.7 & 0.99 & ns \\
\hline Grass odour & 0.6 & 1.1 & 0.93 & $*$ & 0.09 & 0.06 & 0.22 & ns \\
\hline Mouldy odour & & & & & 0.2 & 0.2 & 0.41 & ns \\
\hline Hazelnut odour & 0.8 & 1.2 & 1.26 & ns & & & & \\
\hline Walnut odour & 0.4 & 0.5 & 0.92 & ns & & & & \\
\hline Persistant odour & & & & & 4.2 & 4.1 & 1.17 & $\mathrm{~ns}$ \\
\hline Piquant odour & & & & & 0.6 & 0.4 & 0.5 & ns \\
\hline Rancid odour & & & & & 0.3 & 0.2 & 0.66 & ns \\
\hline Vanilla odour & 0.9 & 1.1 & 1.24 & ns & & & & \\
\hline
\end{tabular}


Table IV. Continued.

\begin{tabular}{|c|c|c|c|c|c|c|c|c|}
\hline \multirow{2}{*}{$\begin{array}{l}\text { Cheese } \\
\text { Diet }\end{array}$} & \multicolumn{4}{|c|}{ Cantalet } & \multicolumn{4}{|c|}{ Saint-Nectaire } \\
\hline & $S$ & $\mathrm{H}$ & $\mathrm{RSD}^{1}$ & Sig. $^{2}$ & $S$ & $\mathrm{H}$ & $\mathrm{RSD}^{1}$ & Sig. $^{2}$ \\
\hline Aroma intensity & 3.6 & 3.8 & 0.85 & ns & 5.4 & 5.2 & 0.76 & ns \\
\hline Citrus fruits aroma & 0.9 & 1.4 & 1.15 & $*$ & & & & \\
\hline Sour aroma & & & & & 0.4 & 0.4 & 0.68 & ns \\
\hline Alcohol aroma & 0.2 & 0.02 & 0.58 & ns & & & & \\
\hline Garlic aroma & 0.6 & 0.6 & 0.61 & ns & & & & \\
\hline Butter aroma & 2.4 & 2.8 & 1.30 & $\mathrm{~ns}$ & 0.8 & 0.7 & 0.77 & ns \\
\hline Caramel aroma & 0.4 & 0.6 & 0.83 & ns & & & & \\
\hline Fungus aroma & & & & & 0.14 & 0.06 & 0.33 & ns \\
\hline Chemical aroma & 0.5 & 0.1 & 0.78 & $*$ & & & & \\
\hline Acidified cream aroma & 0.9 & 0.6 & 1.03 & ns & & & & \\
\hline Fresh cream aroma & 1.5 & 1.5 & 1.43 & ns & & & & \\
\hline Silage aroma & & & & & 0.02 & 0.05 & 0.21 & ns \\
\hline Spicy aroma & 0.3 & 0.5 & 0.71 & ns & & & & \\
\hline Hay aroma & 0.6 & 1.0 & 0.91 & ns & & & & \\
\hline Fruity aroma & & & & & 0.7 & 0.7 & 1.03 & ns \\
\hline Grass aroma & 0.6 & 0.6 & 1.10 & ns & 0.03 & 0.07 & 0.25 & ns \\
\hline Mouldy aroma & & & & & 0.3 & 0.2 & 0.33 & ns \\
\hline Hazelnut aroma & 0.9 & 1.4 & 1.28 & ns & & & & \\
\hline Walnut aroma & 0.5 & 0.7 & 1.12 & ns & & & & \\
\hline $\begin{array}{l}\text { Fresh milk product } \\
\text { aroma }\end{array}$ & & & & & 0.8 & 0.9 & 0.75 & ns \\
\hline Rancid aroma & & & & & 0.05 & 0.3 & 0.41 & $*$ \\
\hline Typical aroma & & & & & 5.3 & 5.3 & 0.83 & ns \\
\hline Vanilla aroma & 1.1 & 1.2 & 1.4 & $\mathrm{~ns}$ & & & & \\
\hline Acid flavour & 0.2 & 0.2 & 0.49 & ns & 1.6 & 1.3 & 1.23 & ns \\
\hline Bitter flavour & 0.2 & 0.3 & 0.48 & ns & 0.9 & 1.0 & 0.99 & ns \\
\hline Salt flavour & 3.0 & 3.3 & 1.0 & ns & 5.2 & 5.1 & 0.57 & ns \\
\hline Sweetened flavour & 1.8 & 1.9 & 1.0 & ns & & & & \\
\hline Astringent flavour & 0.4 & 0.6 & 0.57 & ns & 0.3 & 0.4 & 0.66 & ns \\
\hline Metallic flavour & 0.3 & 0.2 & 0.41 & ns & & & & \\
\hline Piquant & 0.2 & 0.2 & 0.49 & $\mathrm{~ns}$ & 0.5 & 0.4 & 0.54 & ns \\
\hline Persistent flavour & 3.1 & 3.5 & 0.79 & $*$ & 5.3 & 5.0 & 0.92 & ns \\
\hline
\end{tabular}

${ }^{1}$ Residual standard deviation.

2 Significance of difference : $* P<0.05$; $* * P<0.01$; *** $P<0.001$; ns: not significant.

characteristics of Sn cheeses [28]. In return, we found a stronger dietary effect on the sensory characteristics of Ca cheeses, which was consistent with our hypothesis on the existence of interactions between feeding factors and cheese variety. This interaction 
does not appear to be linked to the performance of the two groups of trained assessors, insofar as the hedonistic appreciation made by the same jury of both cheeses revealed a more marked effect of the diet on $\mathrm{Ca}$ than on $\mathrm{Sn}$ cheeses. This interaction appeared to confirm the hypotheses of Coulon et al. [9] who, in a synthesis of different experimental results obtained with different cheese models, observed that some upstream factor effects would be all the more important as the size of cheeses is bigger. The size of a cheese is related to the technological model, and beyond this characteristic, the ecology of the whole system is involved.

In our study, regarding texture, the effect of diet was not exactly the same in Sn and $\mathrm{Ca}$ cheeses: $\mathrm{H}$ Sn cheeses were less gritty and $\mathrm{H} \mathrm{Ca}$ cheeses more melting and mellow. These observations, in particular about melting and mellowness, are surprising as they were not revealed by the instrumental measurements and were opposed to the expected effect of diet when we consider the differences in cheese gross composition. Both $\mathrm{Ca}$ and $\mathrm{Sn}$ cheeses made from $\mathrm{H}$ milk were richer in nitrogen and poorer in fat in relation to the fat/protein ratio of the milks used for cheesemaking. The effect of diet is not linked to proteolysis. It could be explained partly by the higher proportion of low-melting-point fatty acids noted in $\mathrm{H}$ milks by comparison with $\mathrm{S}$ milks. This result (not shown) was obtained in the individual milks of 8 out of the 14 cows of each group [10]. Considering the texture appreciation, the diet changed it only in the case of $\mathrm{Ca}$ cheese. This result could be linked to the very different curd structure of $\mathrm{Ca}$ and $\mathrm{Sn}$ cheeses, leading to differences in the expression of dietary effect.

Finally, the main interaction between diet and cheese variety concerns the flavour. Unfortunately, this study provided only a few analytic elements to explain the stronger characteristics of the $\mathrm{Ca}$ cheeses derived from the $\mathrm{S}$ diet. It did not appear to be linked to the proteolytic indices measured. Otherwise, we may hypothesise that the more significant dietary effect noted in $\mathrm{Ca}$ cheeses could be indirectly linked to their larger size. In fact, differences in technological process lead to differences in the mechanisms of ripening. In small-size cheeses such as Saint-Nectaire, the curd/rind ratio is low so the rind microbial flora has a more important role for the formation of sensory properties than in Cantal cheese, where the curd/rind ratio is higher. Because the rind microbial flora is added during the cheesemaking, we can hypothesise that the animals' feeding method has a marginal effect on it. In bigger cheeses such as Cantal, where the ripening process occurs principally inside the curd, the native characteristics of milk are much more influent on cheese final characteristics.

In addition, we have to keep in mind that the interaction observed could be modulated by the cheesemaking parameters chosen in each cheese variety. Indeed, we know the effect of upstream factors on cheese sensory properties may vary for a given cheese variety according to cheesemaking parameters such as partial skimming [31], pasteurisation [11], acidification kinetics [19] or ripening time [3]. In particular, in this study it would have been interesting to analyse cheeses after different ripening times or using different cheesemaking procedures in order to ensure that the effects of diet are greater between two cheese varieties than within one cheese variety.

\section{CONCLUSION}

This study made it possible to specify the role played by the grass forage type in the determination of cheese sensory characteristics. Its originality lies in the comparison of two cheese types in the same study, showing that this effect could vary according to the cheese type. This interaction was indirectly suspected in other studies, but was for the first time evidenced by this study. This result complements those already obtained separately for different cheese varieties.

Also, this study has raised an important issue on the upstream factor effect: what results obtained for one cheese model are transposable to other ones? However, we cannot forget that the data were obtained at a given ripening time for each cheese: the latter was the common ripening time where 
$\mathrm{Ca}$ and $\mathrm{Sn}$ cheeses are eaten but not necessarily the best one to optimise the dietary differences. Finally, this work has not elicited any explanation as to the mechanisms of upstream factor expression. The understanding of these mechanisms would lead to an answer to the previous question.

Acknowledgements: This work was supported by an AQS programme of the French Government and the Pôle fromager AOC Massif Central. The authors acknowledge E. Albaret and his staff for the samplings, R. Lavigne for the cheesemaking, H. Dubroeucq and his assessors for the milk sensory analyses, F. Maçna for the nitrogen measurements and M.F. Mahé who characterised the genetic variants of lactoprotein. English proof-reading by P. RousseauCunningham.

\section{REFERENCES}

[1] AFNOR, Sensory analysis. Methodology. Triangle test, Standard NF V 09-013, Agence française de normalisation, Paris, France, 1983.

[2] AFNOR, Microbiology analysis of food products. Routine method for microorganism counting. Count technique for colonies obtained at $30{ }^{\circ} \mathrm{C}$, Standard NF V 08-051, Agence française de normalisation, Paris, France, 1992.

[3] Agabriel C., Martin B., Sibra C., Bonnefoy J.C., Montel M.C., Didienne R., Hulin S., Effect of dairy production systems on the sensory characteristics of Cantal cheeses: a plant-scale study, Anim. Res. 53 (2004) 221234.

[4] Ardö Y., Evaluating proteolysis by analysing the $\mathrm{N}$ content of cheese fractions, Bull. Int. Dairy Fed. 337 (1999) 4-9.

[5] Bertoni G., Calamari L., Maianti M.G., Producing specific milks for speciality cheeses, Proc. Nutr. Soc. 60 (2001) 231-246.

[6] Cerf O., Bergère J.L., La numération des spores de Clostridium et son application au lait et aux produits laitiers. II. Numération des différents groupes de Clostridium, Lait 48 (1968) 501-519.

[7] Corrieu G., Spinnler H., Picque D., Jomier Y., Method of revealing and monitoring the acidifying activity of fermentation agents in fermentation vats and device for implementing it, French Patent Application FR2629612, 1989.
[8] Coulon J.B., Pradel P., Verdier I., Effect of forage conservation (hay or silage) on chemical composition of milk, Ann. Zootech. 46 (1997) 21-26.

[9] Coulon J.B., Delacroix-Buchet A., Martin B., Pirisi A., Relationships between ruminant management and sensory characteristics of cheeses: a review, Lait 84 (2004) 221-241.

[10] Ferlay A., Verdier-Metz I., Pradel P., Martin B., van der Horst H., Ballot N., Chilliard Y., Effets respectifs de l'alimentation et de la transformation fromagère sur la composition en acides gras d'intérêt nutritionnel de fromages de type Saint-Nectaire ou Cantalet, in: Proceedings of $9 \mathrm{e}$ Rencontres autour des Recherches sur les Ruminants, 2002, Paris, France, p. 367.

[11] Fernandez-Garcia E., Carbonell M., Nunez M., Volatile fraction and sensory characteristics of Manchego cheese. 1. Comparison of raw and pasteurized milk cheese, J. Dairy Res. 69 (2002) 579-593.

[12] Grappin R., Coulon J.B., Terroir, lait et fromage : éléments de réflexion, in: Proceedings of $3^{\mathrm{e}}$ Rencontres sur les Recherches autour des Ruminants, 1996, Paris, France, pp. 21-28.

[13] IDF, Determination of the total solids contents: gravimetric determination (cheese and processed cheese), Standard 4A, Int. Dairy Fed., Brussels, Belgium, 1982.

[14] IDF, Determination of Total Phosphorus content: spectrometric method (milk). Standard 42B, Int. Dairy Fed., Brussels, Belgium, 1990.

[15] IDF, Determination of calcium content: flame atomic absorption spectrometric method (Milk and dried milk), Standard 154, Int. Dairy Fed., Brussels, Belgium, 1992.

[16] IDF, Numération des cellules somatiques du lait, Standard 148A, Int. Dairy Fed., Brussels, Belgium, 1995.

[17] IDF, Determination of fat content: general guidance on the use of butyrometric methods (milk and milk products), Standard 152A, Int. Dairy Fed., Brussels, Belgium, 1997.

[18] Keen A.R., Wilson R.D., Effect of breed on colour and flavour, in: Proceedings of Milk Fat Flavour Forum, Palmerson North, New Zealand, 1992, pp. 50-54.

[19] Martin B., Coulon J.B., Facteurs de production du lait et caractéristiques des fromages. I. Influence des facteurs de production sur l'aptitude à la coagulation des laits de troupeaux, Lait 75 (1995) 61-80.

[20] Martin B., Ferlay A., Pradel P., Rock E., Grolier P., Dupont D., Gruffat D., Besle J.M., 
Ballot N., Chilliard Y., Coulon J.B., Variability of the composition of milk in components having a nutritional interest according to the cow's diet, in: Proceedings of 9e Rencontres autour des Recherches sur les Ruminants, 2002, Paris, France, pp. 347-350.

[21] McMahon D.J., Brown R.J., Evaluation of Formagraph for comparing rennet solutions, J. Dairy Sci. 65 (1982) 1639-1642.

[22] Michel V., Hauwuy A., Chamba J.F., La flore microbienne des laits crus de vache: diversité et influence des conditions de production, Lait 81 (2001) 575-592.

[23] Morgan M.E., Pereira R.L., Volatile constituents of grass and corn silage. I. Steam distillates, J. Dairy Sci. 45 (1962) 457-466.

[24] Remeuf F., Cossin V., Dervin C., Lenoir J., Tomassone R., Relations entre les caractères physico-chimiques des laits et leur aptitude fromagère, Lait 71 (1991) 397-421.

[25] SAS Institute Inc., SAS User's Guide: Statistics, SAS Institute Inc., Cary, NC, USA, 1987.

[26] Shipe W.F., Ledford R.A., Peterson R.D., Scanlan R.A., Geerken H.F., Dougherty R.W., Morgan M.E., Physiological mechanisms involved in transmitting flavors and odors to milk. II. Transmission of some fla- vor components of silage, J. Dairy Sci. 45 (1962) 477

[27] Urbach G., Effect of feed on flavor in dairy foods, J. Dairy Sci. 73 (1990) 3639-3650.

[28] Verdier-Metz I., Coulon J.B., Pradel P., Viallon C., Berdagué J.L., Effect of forage conservation (hay or silage) and cow breed on the coagulation properties of milks and on the characteristics of ripened cheeses, J. Dairy Res. 65 (1998) 9-21.

[29] Verdier-Metz I., Coulon J.B., Pradel P., Viallon C., Albouy H., Berdagué J.L., Effect of the botanical composition of hay and casein genetic variants on the chemical and sensory characteristics of ripened Saint-Nectaire type cheeses, Lait 80 (2000) 361-370.

[30] Verdier-MetzI., Coulon J.B., Viallon C., Pradel P., Effet de la conservation du fourrage sur les caractéristiques physico-chimiques et sensorielles des fromages, in: Proceedings of $7^{\mathrm{e}}$ Rencontres sur les Recherches autour des Ruminants, 2000, Paris, France, p. 318.

[31] Verdier-Metz I., Martin B., Pradel P., Coulon J.B., Effet conjoint de la race et de la nature du fourrage sur les caractéristiques des fromages : interaction avec la technologie mise en œuvre, in: Proceedings of $9^{e}$ Rencontres autour des Recherches sur les Ruminants, 2002, Paris, France, pp. 355-358. 